\title{
Hubungan antara kehilangan gigi dengan fungsi kognisi dan fungsi memori pada lansia penghuni Panti Sosial Tresna Werdha (PTSW) Senjarawi Kota Bandung
}

\author{
Kartika Indah Sari*, Murnisari Darjan*, Nanan Nur’aeny**, Lulu Eva Rakhmilla*** \\ *Departemen Biologi Oral, Fakultas Kedokteran Gigi, Universitas Padjajaran, Bandung, Jawa Barat, Indonesia \\ **Departemen IImu Penyakit Mulut, Fakultas Kedokteran Gigi, Universitas Padjajaran, Bandung, Jawa Barat, Indonesia \\ ***Departemen Epidemiologi dan Biostatistik, Fakultas Kedokteran, Universitas Padjajaran, Bandung, Jawa Barat, Indonesia \\ *JI Sekeloa Selatan No. 1, Bandung, Jawa Barat, Indonesia; e-mail: kartika.sari@fkg.unpad.ac.id
}

Submisi: 25 Oktober 2016; Penerimaan: 25 Februari 2017; Publikasi online: 31 Agustus 2017

\begin{abstract}
ABSTRAK
Kehilangan gigi dilaporkan berhubungan dengan penyakit Alzheimer dan demensia. Penelitian ini bertujuan untuk mengetahui hubungan antara kehilangan gigi dengan fungsi kognisi dan fungsi memori yang diperiksa menggunakan lembar MMSE (mini mental state examination) pada lansia di Panti Sosial Tresna Wreda (PSTW) Senjarawi Kota Bandung. Metode penelitian menggunakan desain potong lintang. Teknik pengambilan sampel concecutive sampling. Sampel penelitian dipilih sesuai kriteria inklusi meliputi sehat fisik (yang ditandai dengan dapat melakukan kegiatan sehari-hari secara mandiri) dan mampu berkomunikasi dengan baik, usia minimal 60 tahun, dan mandiri. Hasil pemeriksaan pada 19 orang lansia yang terdiri dari 12 orang wanita dan 7 orang laki-laki menemukan karakteristik subjek penelitian pada kelompok penurunan fungsi kognisi dan penurunan fungsi memori yaitu usia rata-rata $(75,89 ; 76,32)$, tingkat pendidikan SD $(66,7 \% ; 77,8 \%)$, jenis kelamin perempuan $(41,7 \% ; 66,7 \%)$, aktivitas fisik berupa olahraga ringan $(50 \% ; 66,7 \%)$ dan penyakit yang diderita berupa hipertensi $(58,3 \% ; 75 \%)$, penyakit muskuloskeletal (50\%; $75 \%)$. Melalui uji Pearson chi square tidak terlihat hubungan yang signifikan antara kehilangan gigi dengan fungsi kognisi $p=1,318(p>0,05)$. Begitu pula melalui uji Pearson chi square, $p=0,333(p>0,05)$ dapat dijelaskan bahwa tidak terlihat hubungan yang signifikan antara kehilangan gigi dengan fungsi memori. Simpulan terdapat kecenderungan penurunan fungsi kognisi dan fungsi memori pada kehilangan gigi, namun hal ini secara statistik tidak terlihat korelasi yang signifikan. Penelitian lanjutan diperlukan dengan jumlah sampel yang lebih banyak sehingga diperoleh data yang homogen dan terdistribusi dengan baik.
\end{abstract}

Kata kunci: fungsi kognisi; kehilangan gigi; lansia; MMSE

\begin{abstract}
Correlation between tooth loss and cognitive and memory function in elderly residents at Social Home Tresna Werdha (PTSW) Senjarawi, Bandung City. Tooth loss is reported to be linked with Alzheimer's disease and dementia. This study aimed to identify the correlation between tooth loss, cognitive and memory functions examined using a MMSE (mini-mental state examination) test to the elderly residents at Panti Sosial Tresna Wreda (PSTW) Senjarawi, Bandung. The research method used cross sectional design. The sampling was selected using concecutive sampling technique. The sample was selected according to the inclusion criteria including physical health (marked by their ability to perform daily activities independently) and ability to communicate well, at least 60 years of age, and independent. The results of the examination on 19 elderly people consisting of 12 females and 7 males showed that the research subjects fall in the category of having a decline in their cognitive and memory function, that is at the average age (75.89; 76.32), education level of elementary school (66.7\%; 77.8\%), female (41.7\%; 66.7\%), physical activity in the form of light exercise (50\%; 66.7\%) and having hypertension (58.3\%; 75\%), having musculoskeletal disorder (50\%; $75 \%)$. Pearson chi-square test showed that there is no significant correlation between tooth loss and cognitive function $p=1.318(p>0.05)$. Similarly, Pearson chi-square test of $p=0.333(p>0.05)$ indicates that there is significant correlation between tooth loss and memory function. It can be concluded that there is a tendency of a decline in both cognitive function and memory function in tooth loss, but this is not evident statistically. Future research involving a larger number of samples is needed to obtain homogeneous and well-distributed data.
\end{abstract}

Keywords: cognitive function; tooth loss; elderly; MMSE

\section{PENDAHULUAN}

Lansia dengan kemampuan mengunyah yang baik akan memiliki kualitas pencernaan yang baik. Kualitas pencernaan yang baik berdampak pada peningkatan kualitas hidup lansia. Hasil penelitian mengenai gambaran permasalahan gigi dan mulut pada populasi lansia ditemukan bahwa banyak gigi yang hilang yang berdampak pada kualitas hidup 
lansia yaitu pada dimensi keterbatasan fungsi. ${ }^{1}$ Jumlah penduduk Indonesia yang lebih dari 200 juta jiwa pada tahun 2000, 7,5\% atau 15 juta jiwa adalah penduduk lansia. Pada tahun $2000-2005$, usia harapan hidup (UHH) penduduk Indonesia adalah 67,8 tahun. Pada tahun $2020-2025$, UHH penduduk Indonesia meningkat menjadi 73,7 tahun dan diperkirakan jumlah lansia akan mencapai 28,8 juta atau $11,34 \%$ dari total populasi. ${ }^{2}$

Kehilangan gigi banyak dialami oleh lansia seiring dengan bertambahnya usia. Lansia cenderung memilih makanan yang lunak atau mudah untuk dikunyah. Hal ini akan berdampak pada berkurangnya pemenuhan nutrisi. ${ }^{3}$ Kehilangan gigi dilaporkan pula berhubungan dengan penyakit Alzheimer's disease (AD) dan demensia. ${ }^{4,5}$ Penyakit demensia (gangguan pikun) umumnya erat karena faktor penuaan dan belum banyak penelitian yang mengaitkan dengan jumlah gigi yang masih tersisa di rongga mulut lansia. Penelitian yang dilakukan oleh Okamoto et a/ $/ \$$ pada lansia melaporkan bahwa terdapat hubungan antara kehilangan gigi dengan fungsi kognisi. ${ }^{6}$

Fungsi rongga mulut dan status kesehatan rongga mulut serta fungsi kognisi berhubungan erat dengan kesehatan fisik, mental dan sosial. Kesehatan fisik dan mental berdampak pada peningkatan kualitas hidup. Begitu pula halnya dengan penurunan fungsi kognisi yang berkaitan dengan kemampuan learning dan memory (belajar dan mengingat) akan mempengaruhi interaksi sosial yang pada akhirnya juga akan berdampak pada kualitas hidup lansia.

Melalui penelitian yang dilakukan pada hewan coba, aktivitas mengunyah makanan padat atau keras dan makanan lunak atau bubur berdampak pada perubahan struktur jaringan hipokampus di otak. Kepadatan neuron atau perubahan struktur jaringan pada hipokampus hewan coba mencerminkan adanya perubahan waktu tempuh tikus atau mencit dengan menggunakan uji renang morris water maze (MWM). ${ }^{7-10}$ Perubahan ini mewakili perubahan dalam kapasitas memori.

Lansia erat hubungannya dengan penurunan semua fungsi organ. Penurunan ini dapat terjadi secara fisiologik normal ataupun patologik karena kelainan yang terjadi pada organ, termasuk penurunan fungsi otak. Berdasarkan pengetahuan penulis, masih belum banyak penelitian yang dilakukan untuk melihat hubungan antara kehilangan gigi dan fungsi kognisi pada manusia. Oleh karena alasan tersebut di atas penulis tertarik untuk meneliti topik tersebut. Penelitian ini bertujuan mengetahui hubungan antara kehilangan gigi dengan fungsi kognisi yang dapat dijadikan sebagai informasi baru bagi dokter gigi.

\section{METODE PENELITIAN}

Penelitian deskriptif kuantitatif potong lintang (cross-sectional). Penelitian dilakukan pada lansia penghuni Panti Sosial Tresna Werda (PTSW) "Senjarawi" di kota Bandung yang terpilih secara acak dari enam PSTW yang ada di kota Bandung. Pengambilan sampel menggunakan teknik concecutive sampling. Sampel penelitian dipilih sesuai kriteria inklusi meliputi sehat fisik dan mampu berkomunikasi verbal dengan baik, usia minimal 60 tahun. Sehat fisik di sini dapat melakukan aktivitas dasar secara mandiri (sehat fisik). Sehat fisik dinilai dengan kemampuan lansia melakukan aktivitas bangun tidur, mandi,berpakaian, makan/ minum, buang air besar/kecil, pergi tidur secara mandiri. Sedangkan kriteria ekslusi, yaitu tidak bersedia mengikuti penelitian sampai selesai dan subjek penelitian sedang mengkonsumsi obatobatan khusus memori atau multivitamin untuk meningkatkan daya ingat berdasarkan keterangan yang diperoleh dari dokter jaga. Penelitian dilakukan pada bulan September 2014 sampai dengan Januari 2015.

Prosedur penelitian ditetapkan dengan mengumpulkan subjek penelitian pada ruangan tertentu sebagai tahap awal, kemudian peneliti menjelaskan maksud dan tujuan penelitian, serta manfaat (Gambar 1). Tahap kedua, subjek penelitian yang bersedia berpartisipasi pada penelitian, menandatangani persetujuan penelitian (informed consent). Tahap selanjutnya wawancara dan dilakukan pemeriksaan fisik, meliputi; pengukuran tekanan darah, pengukuran tinggi badan (TB) dan berat badan (BB) untuk menentukan body massa index (BMI), dan pemeriksaan kognisi 
menggunakan lembar pengisisan tes mini mental state examination (MMSE). Tes MMSE digunakan sebagai alat untuk menskrening gangguan kognisi. Pemeriksaan MMSE meliputi penilaian orientasi, registrasi, perhatian, dan kalkulasi, recall test, serta bahasa. Subjek dinilai secara kuantitatif pada fungsi kognisi secara umum. Skor MMSE adalah $0-30$. Penilaian fungsi kognisi normal dengan skor MMSE $24-30$ dan penurunan fungsi kognisi dengan skor MMSE $0-23 .^{6}$

Penilaian fungsi memori diperoleh dari skor recall test yang merupakan bagian dari pemeriksaan MMSE. Skor recall test adalah $0-3$. Penilaian terhadap fungsi memori normal dengan skor recall test $3-2$, sedangkan penilaian terhadap penurunan fungsi memori dengan skor recall test 1 $-0 .{ }^{6}$ Setelah pemeriksaan terhadap fungsi kognisi dan fungsi memori, subjek penelitian melakukan pemeriksaan rongga mulut untuk melihat kondisi rongga mulut dalam hal ini jumlah gigi yang hilang. Gigi goyang dan sisa akar yang terindikasi untuk dilakukan pencabutan dimasukkan ke dalam gigi yang hilang. Alur penelitian seperti terlihat pada gambar 2. Data yang sudah dikumpulkan akan dianalisa dengan menggunakan program SPSS V.22 for windows. Data ditampilkan dalam bentuk tabel untuk mengetahui proporsi karakteristik responden, yang tersiri dari usia, jenis kelamin, pendidikan terakhir, tekanan darah, BMI, aktivitas fisik, dan penyakit yang diderita. Tabulasi distribusi frekuensi fungsi kognisi dan fungsi memori dibuat berdasarkan kategorik kehilangan gigi dipeeoleh. Kategori kehilangan gigi dibedakan atas 3 kelompok, yaitu kelompok I kehilangan 22-32 gigi, kelompok II kehilangan 11-21 gigi dan kelompok III kehilangan $22-32{ }^{6}$

Data dikatakan homogen diketahui melalui pemeriksaan uji beda. Pada pemeriksaan uji beda data variabel numerik, peneliti menggunakan uji $t$ test dan untuk uji beda data kategorik menggunakan uji chi-square. Data karakteristik homogen untuk kedua kelompok yang dibandingkan apabila nilai $p>0,05$. Selanjutnya untuk melihat hubungan antara kehilangan gigi dengan fungsi kognisi dan fungsi memori diperlukan deskripsi analisa dengan menggunakan uji korelasi Person Chi-square dengan taraf signifikansi $p<0,05$.
Dalam rangka menjamin keamanan dan kesejahteraan manusia selaku subjek penelitian kesehatan dengan mempertimbangkan aspek autonomy, beneficient, non-maleficient dan justice, persetujuan etik (ethical clearance) diperoleh dari Komite Etik penelitian kesehatan Fakultas Kedokteran Unpad (KEPK-FK Unpad). Lembaran informed consent diberikan dan ditandatangani oleh masing-masing subjek penelitian yang bersedia berpartisipasi dalam penelitian.

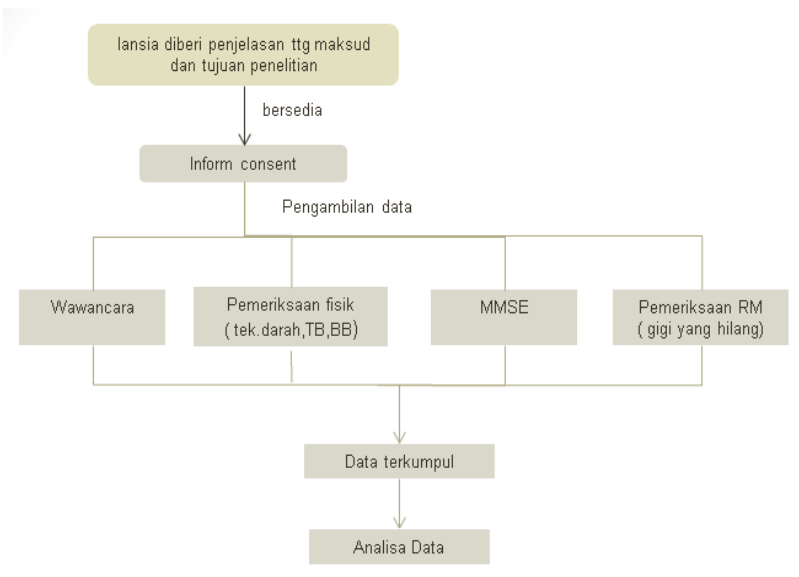

Gambar 1. Alur penelitian

\section{HASIL PENELITIAN}

Dari Tabel 1 terlihat rata-rata usia lansia adalah 76 tahun, sebagian berjenis kelamin perempuan (63\%), dan berpendidikan tingkat SD $47,4 \%$. Tekanan darah sistolik tergolong kategori hipertensi tingkat 1, yaitu $140-159 \mathrm{mmHg}$ dan tekanan darah diastolik tergolong normal, yaitu $<80 \mathrm{mmHg}$. Lansia melakukan aktivitas fisik berupa olahraga ringan sebanyak $94,7 \%$.

Dari penelitian diperoleh hasil bahwa uji beda data numerik dan kategorik pada kedua pasang kelompok yang dibandingkan, yaitu antara kelompok fungsi kognisi normal, skor MMSE (2430) dengan kelompok penurunan fungsi kognisi, skor MMSE (0-23) dan antara kelompok fungsi memori normal, skor recall test (1-0) dengan kelompok penurunan fungsi memori, skor recall test (3-2) diperoleh hasil $p>0,05$, yang artinya bahwa kedua pasang kelompok yang dibandingkan adalah sama atau tidak berbeda homogen seperti terlihat pada Tabel 1. 
Tabel 1. Karakteristik subjek penelitian

\begin{tabular}{lc}
\hline Karakteristik subjek & $\mathrm{n}=19(\%)$ \\
\hline Usia, tahun, rata-rata; SD & 76,$32 ; 6,056$ \\
Jenis kelamin, perempuan(\%) & 63,2 \\
Tingkat pendidikan (\%) & \\
$\quad$ Tidak bersekolah & 21,1 \\
SD & 47,4 \\
SMP & 15,8 \\
SMA & 15,8 \\
Sistolik, mmHg, rata-rata; SD & $140 ; 12,019$ \\
Diastolik, mmHg, rata-rata; SD & 74,$21 ; 9,612$ \\
Kegiatan fisik (\%) & \\
$\quad$ Olahraga ringan & 94,7 \\
$\quad$ Tidak berolahraga & 5,3 \\
Penyakit yang diderita (\%) & \\
\hline Hipertensi & 63,2 \\
\hline Penyakit metabolik & 10,5 \\
\hline Penyakit muskuloskeletal & 21,1 \\
\hline Lain-lain & 5,3 \\
\hline
\end{tabular}

Pada data yang menunjukkan tekanan sistolik kelompok penurunan fungsi kognisi (023) dan kelompok fungsi kognisi normal (24-30) memperlihatkan hasil yang berbeda. Hasil uji beda $p=0,007$ (signifikan $p>0,05$ ). Analisa data untuk variabel tekanan sistolik bermakna tidak homogen, seperti terlihat pada Tabel 1.

Selanjutnya tabulasi distribusi frekuensi fungsi kognisi dan fungsi memori berdasarkan kehilangan gigi dapat dilihat pada Gambar 2. Hasil penelitian menjelaskan bahwa dari seluruh lansia yang mengalami kehilangan gigi, rasio terbesar lansia yang mengalami penurunan fungsi kognisi (skor MMSE 0-23) yaitu pada kategori kehilangan gigi 22-32 buah dibandingkan dengan lansia dengan fungsi kognisi normal (skor kognisi 2430 ).

Tabel 2. Karakteristik subjek penelitian berdasarkan atas kategori skor kognisi dan skor memori

\begin{tabular}{|c|c|c|c|c|c|c|}
\hline Karakteristik subjek & $\begin{array}{c}\text { Skor } \\
\text { Kognisi } \\
0-23\end{array}$ & $\begin{array}{l}\text { Skor Kognisi } \\
24-30\end{array}$ & $\mathrm{P}$ & $\begin{array}{c}\text { Skor } \\
\text { Memori } \\
1-0\end{array}$ & $\begin{array}{c}\text { Skor } \\
\text { memori } \\
3-2\end{array}$ & $P$ \\
\hline Usia, tahun (rata-rata; SD) & 75,$89 ; 5,159$ & 76,$70 ; 7,025$ & $0,776^{*}$ & 76,$62 ; 4,482$ & 75,$67 ; 9,114$ & $0,817^{*}$ \\
\hline Jenis kelamin, perempuan (\%) & 41,7 & 58,3 & $0,65^{*}$ & 66,7 & 33,3 & $0,829^{*}$ \\
\hline \multicolumn{7}{|l|}{ Tingkat pendidikan (\%) } \\
\hline Tidak bersekolah & 50 & 50 & & 75 & 25 & \\
\hline SD & 66,7 & 33,3 & \multirow{3}{*}{$0,272^{* *}$} & 77,8 & 22,2 & \multirow{3}{*}{$0,540^{* *}$} \\
\hline SMP & 0 & 100 & & 33,3 & 66,7 & \\
\hline SMA & 33,3 & 66,7 & & 66,7 & 33,3 & \\
\hline BMI, kg/m², rata-rata; SD & 23,$446 ; 4,590$ & 23,$594 ; 4,136$ & $0,942^{*}$ & 24,$023 ; 4,203$ & 22,$443 ; 4,481$ & $0,485^{*}$ \\
\hline Sistolik, mmHg, rata-rata; SD & 147,$78 ; 12,019$ & $133 ; 6,749$ & $0,007^{*}$ & 141,$54 ; 8,987$ & 136,$67 ; 17,512$ & $0,543^{*}$ \\
\hline Diastolik, $\mathrm{mmHg}$, rata-rata; SD & 73,$33 ; 12,247$ & $75 ; 7,071$ & $0,726^{*}$ & 71,$54 ; 6,887$ & $80 ; 12,649$ & $0,172^{*}$ \\
\hline \multicolumn{7}{|l|}{ Kegiatan fisik (\%) } \\
\hline Olahraga ringan & 50 & 50 & \multirow{2}{*}{$0,526^{\star *}$} & 66,7 & 33,3 & \multirow{2}{*}{$0,684^{\star *}$} \\
\hline Tidak berolahraga & 0 & 100 & & 100 & 0 & \\
\hline \multicolumn{7}{|l|}{ Penyakit yg diderita (\%) } \\
\hline Hipertensi & 58,3 & 41,7 & \multirow{4}{*}{$0,323^{* *}$} & 75 & 25 & \multirow{4}{*}{$0,351^{\star *}$} \\
\hline Penyakit metabolik & 0 & 100 & & 50 & 50 & \\
\hline Penyakit muskuloskeletal & 50 & 50 & & 75 & 25 & \\
\hline Lain-lain & 0 & 100 & & 0 & 100 & \\
\hline
\end{tabular}

*uji beda Independent $t$ test; ${ }^{* *}$ uji beda Fisher exact, $p>0,05$ 


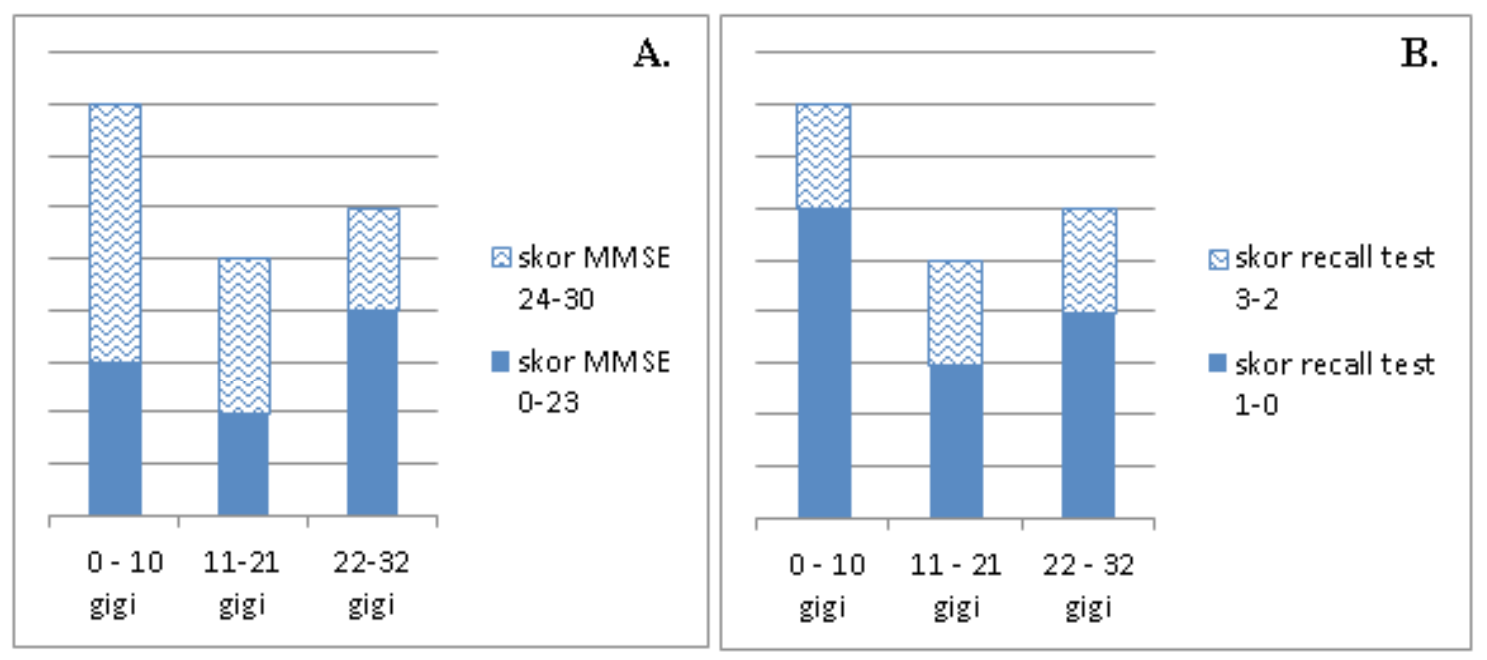

Gambar 2. Tabulasi distribusi frekuensi berdasarkan kehilangan gigi dengan: (A) Fungsi Kognisi, uji Pearson chi square $=1.318, p>0.05)$ dan $(B)$ Gangguan Memori, uji Pearson chi square $=0.333, p>0.05)$. Taraf signifikansi $p<0,05$.

Pada kategori kehilangan gigi dengan jumlah yang lebih sedikit yaitu 0-10 buah dan 11-21 buah, kehilangan gigi belum terlihat mempengaruhi fungsi kognisi. Melalui uji Pearson chi square $=1,318$, $p>0,05$ dapat dijelaskan pula bahwa tidak terlihat hubungan yang signifikan antara kehilangan gigi dengan fungsi kognisi seperti terlihat pada Gambar $2(A)$.

Pada Gambar 2 (B) menjelaskan bahwa jumlah lansia yang mengalami penurunan fungsi memori (skor recall test 1-0) pada semua kelompok kategori kehilangan gigi adalah lebih banyak dibandingkan lansia dengan fungsi memori normal (skor recall test 3-2). Pada kehilangan jumlah gigi yang lebih sedikit (kehilangan gigi 0-10), jumlah lansia dengan penurunan fungsi memori lebih banyak dibandingkan kedua kelompok dengan kategori kehilangan gigi yang lebih banyak. Melalui uji Pearson chi square $=0,333, p>0,05$ dapat dijelaskan pula bahwa tidak terlihat hubungan yang signifikan antara kehilangan gigi dengan fungsi memori seperti terlihat pada Gambar 2 (B).

\section{PEMBAHASAN}

Penelitian dilaksanakan pada PSTW Senjarawi yang terpilih secara acak dari enam lokasi PTSW lainnya di Kota Bandung. Penelitian ini bertujuan memberikan gambaran hubungan antara kehilangan gigi dengan fungsi kognisi dan memori. Batas minimal usia lansia yang digunakan sebagai subjek penelitian adalah 60 tahun. Peneliti berasumsi dengan melakukan penelitian pada lansia yang berada di kompleks hunian yang sama (panti Jompo) data yang diperoleh homogen. Dari hasil penelitian diperoleh rata-rata usia lansia yang mengalami penurunan fungsi kognisi dengan lansia yang mempunyai fungsi kognisi normal adalah $75,89 \pm 5,159$ vs $76,70 \pm 7,025$ dan usia rata-rata lansia yang mengalami penurunan fungsi memori dengan lansia yang mempunyai fungsi memori normal adalah $76,62 \pm 4,48$ vs $75,67 \pm 9,11$.

Jenis kelamin kemungkinan berdampak pula pada penurunan fungsi kognisi dan penurunan pada fungsi memori. Dari hasil penelitian lansia wanita $66,7 \%$ mengalami penurunan fungsi memori. Pada penurunan fungsi kognisi lansia pria menempati posisi lebih banyak dibandingkan lansia wanita ( $58,3 \%$ vs $41,7 \%)$. Dari penelitian ini mengungkapkan bahwa lansia tidak bersekolah dan tamatan SD mengalami penurunan fungsi kognisi dan penurunan fungsi memori lebih banyak dibandingkan lansia dengan tingkat pendidikan yang lebih tinggi (SMP atau SMA). Hal ini kemungkinan dapat dipahami melalui mekanisme memaksimalkan fungsi otak, yaitu dalam proses belajar. Kerja otak yang optimal dapat menunda proses degenerasi yang berlangsung karena efek fisiologis penuaan. Melalui suatu penelitian yang dilakukan pada hewan coba mengungkapkan 
bahwa waktu tempuh pada hewan coba yang melakukan uji renang sebanyak empat set, maka uji set keempat (h-4) waktu tempuhnya lebih pendek antara tikus usia dewasa muda yang melakukan aktivitas fisik dengan kelompok tikus muda yang tidak melakukan aktivitas fisik dengan yang melakukan fisik. ${ }^{10}$

Lansia yang mendiami panti yang berpartisipasi dalam penelitian adalah lansia yang tergolong mandiri, yaitu dapat melakukan aktivitas makan, mandi, buang air besar, berpakaian dan berjalan tanpa bantuan orang lain. Lansia mendiami rumahrumah yang dihuni oleh tiga atau empat lansia. Lansia dapat melakukan aktivitas atau hobby seperti berkebun, bertukang, menjahit mencuci pakaian, memasak, bahkan ke pasar. Pada Tabel 1 dapat dilihat bahwa hampir seluruh lansia (94,7\%) melakukan aktivitas fisik tergolong ringan. Lansia mempunyai aktivitas sekali seminggu keluar untuk kegiatan amal. Lansia menerima kunjungan keluarga, kemudian keluarga dapat membawa lansia keluar panti untuk beralan-jalan sebagai bentuk lain dari aktivatas fisik lansia yang tergolong ringan. Hal ini dapat menguatkan bahwa aktivitas fisik memelihara fungsi kongisi dan fungsi memori.

Aktivitas fisik/latihan fisik atau olahraga sejak lama diketahui dapat meningkatkan fungsi otak Aktivitas fisik berupa olahraga ringan adalah berjalan berkeliling halaman panti selama lebih kurang 30 menit atau lebih. Sehari-hari lansia melakukan aktivitas fisik selain aktivitas dasar (makan, mandi, berpakaian, toilet dan berjalan) berupa menjahit, merajut, berbelanja, bertukang, bercocok tanam dan lain-lain sesuai minat dan kesukaan lansia. Aktivitas fisik mempengaruhi fungsi otak dalam hal ini fungsi kognisi dan fungsi memori. ${ }^{11,12}$

Walaupun aktivitas fisik yang dilakukan lansia tidak terukur berdasarkan, lamanya, frekuensinya dan intensitasnya. Pola hidup selama lansia menghuni panti dapat memelihara kesehatan secara umum. Dari penelitian mengungkapkan bahwa lansia yang melakukan aktivitas fisik yang tergolong ringan lebih sedikit mengalami gangguan fungsi memori dibandingkan lansia yang tidak melakukan gerak badan (olahraga) karena keterbatasan fisik yang berkaitan dengan gangguan muskuloskeletal misalnya, osteoartritis. Selain dapat berpengaruh terhadap penguatan sel-sel otot, olahraga dapat juga memperkuat sel-sel otak. Sehingga olahraga memberi manfaat terhadap meningkatnya kemampuan neuromuskular dan fungsi otak. Telah terbukti bahwa latihan ketahanan dapat merangsang pertumbuhan sel-sel otak dan dapat meningkatkan fungsi kognitif. ${ }^{11,12}$

Berkaitan dengan kehilangan gigi yang banyak dialami oleh lansia, memungkinkan kecenderungan lansia dalam memilih makanan yang lunak atau mudah untuk dikunyah. Hal ini akan berdampak pada berkurangnya aktivitas otot-otot pengunyahan sehingga distribusi aliran darah ke otak pun berkurang. ${ }^{8}$ Dari hasil wawancara mendapatkan gambaran bahwa lansia gemar mengkonsumsi makanan padat atau keras seperti jenis kerupuk. Artinya lansia yang ada di panti mengkonsumsi kombinasi makanan lunak dan keras dalam kesehariannya. Walaupun persentase lansia yang mengalami kehilangan gigi pada setiap kategori kehilangan $0-10,11-21,22-32$ tidak jauh berbeda yaitu $42 \%, 26 \%$ dan $32 \%$. Suatu penelitian mengungkapkan bahwa kehilangan gigi akan menyebabkan kecukupan nutrisi terganggu. ${ }^{13}$ Dari Tabel 1 didapatkan informasi 10,5\% lansia mengalami gangguan metabolik. Gangguan metabolik ini beruba, sembelit, diare dan mual. Dari Tabel 2 dapat dilihat bahwa BMI pada kelompok fungsi kognisi (0-23), yaitu $23,4 \mathrm{~kg} / \mathrm{m} 2$ dan Kelompok fungsi kognisi (24-34), yaitu $23,6 \mathrm{~kg} / \mathrm{m} 2$ tergolong BMI kategori overweight beresiko.

Nutrisi yang diserap oleh tubuh dapat optimal apabila proses pencernaan yang berlangsung berjalan baik. Ketika terdapat banyak gigi yang hilang lansia akan menemui hambatan dalam proses mastikasi yang berlangsung di rongga mulut. Di sisi lain, proses penuaan yang berlangsung fisiologis tidak dapat dihindari yang berdampat pada setiap sistem organ tubuh. Lansia juga kelompok yang beresiko tinggi terhadap berbagai penyakit sehingga dituntut untuk dapat memenuhi nutrisi secara adekuat. Kondisi kesehatan dan penyakit yang diderita lansia berbeda, aktivitas fisik yang berbeda dan perbedaan dalam proses menua itu sendiri, menyebabkan nutri menjadi faktor yang sangat penting diperhatikan. 
Lansia mengalami penurunan dalam pengaturan sistem metabolisme. Perubahan dalam pola ketersediaan enzim sehingga melambatnya kapasitas transportasi zat gizi mencapai sitoplasma. Energi untuk berlangsungnya proes metabolisme pun mengalami penurunan pada lansia. Penurunan ini disebabkan oleh menurunnya jumlah sel dan menurunnya aktivitas fisik yang dilakukan. Dari kondisi lansia tersebut energi yang digunakan (energi expenditure) dan energi yang diperoleh dari makanan (energi intake) berkurang.

Pada penelitian ini, kesehatan rongga mulut merupakan bagian integral dari kesehatan umum. ${ }^{14}$ Kesehatan rongga mulut dan kecukupan nutrisi mempunyai hubungan sinergis. Fungsi pengunyahan yang buruk akan berefek pada pemilihan makanan yang kurang serat dan rendah kandungan gizi. Hal ini akan berdampak pada status kecukupan gizi yang mempengaruhi kualitas hidup bagi populasi lansia. ${ }^{15,16,17}$

Lansia tidak berpikir untuk melakukan perawatan atau penggantian gigi yang hilang dengan gigi tiruan untuk memperbaiki disfungsi mastikasi. Upaya untuk pergi berobat dan mengatasi keluhan tidak dilakukan karena persepsi atau paradigma lansia. Salah satu alasan yang paling menonjol adalah bahwa orang tua atau lansia menganggap disfungsi oral merupakan bagian dari proses alamiah dan konsekuensi usia lanjut sehingga para lansia menerima saja kondisi menurunnya kualitas hidup tersebut tanpa berupaya untuk mendapatkan pertolongan. ${ }^{18}$

Berkaitan dengan adanya pengaruh fungsi mastikasi terhadap aktivitas otak, dari penelitian yang dilakukan pada subjek lansia usia $>65$ tahun menjelaskan bahwa pada kelompok lansia dengan jumlah gigi lebih banyak, daerah permukaan kunyah yang lebih luas dan kekuatan gigitan yang lebih kuat, ternyata tidak ditemukan adanya lansia yang menderita demensia. Akan tetapi pada lansia yang kelengkapan dan fungsi giginya berkurang, pada kelompok lansia ini sebagian besar menderita demensia. Penelitian tersebut sejalan dengan penelitan lain pada lansia sehat dengan gigi yang masih lengkap dibandingkan dengan lansia pemakai protesa penuh (full denture)..$^{19,20}$

\section{KESIMPULAN}

Dari penelitian ini diperoleh hasil bahwa semakin banyak jumlah gigi yang hilang, maka terjadi penurunan fungsi kognisi dan fungsi memori, namun hal ini secara statistik tidak terdapat korelasi yang signifikan. Saran untuk dilakukannya penelitian dengan jumlah sampel yang lebih besar sehingga tidak saja dapat dipenuhi sampel yang homogen dalam jumlah yang relatif banyak, tetapi juga terdistribusi normal. Penelitian berikutnya dapat dilakukan pada hewan coba untuk melihat pengaruh usia pada proses degenerasi sel-sel otak.

\section{UCAPAN TERIMA KASIH}

Ucapan terima kasih kepada Dekan dan Reviewer di lingkungan Fakultas Kedokteran Gigi Universitas Padjadjaran yang telah memberi bantuan dana penelitian yang bersumber dari dana PNBP tahun anggaran 2015. Terima kasih kepada pihak pimpinan Panti Sosial Tresna Werdha "Senjarawi" tempat dilakukannya penelitian.

\section{DAFTAR PUSTAKA}

1. Sari KI, Darjan M, Rizali E. Distribusi permasalahan gigi dan mulut sebagai penentu kualitas hidup masysrakat lanjut usia. Proceding Book, Forum Dies FKG Unpad; 2011.

2. Departemen Kesehatan RI. Pedoman pembinaan kesehatan usia lanjut bagi petugas kesehatan; 2007.

3. Kim JM, Stewart R, Prince M, Kim SW, Yang SJ, Shin IS, Yoon JS. Dental health, nutritional status and recent-onset dementia in a Korean community population. Int J Geriatr Psychiatry. 2007; 22: $850-855$.

4. Gatz M, Mortimer JA, Fratiglioni L, Johansson B, Breg S, Reynolds CA, Pedersen NL. Potentially modifable risk factors for dementia in identical twins. Alzheimer's \& Dementia. 2006; 2: $110-117$.

5. Stein PS, Desrosiers M, Donegan SJ, Yepes JF, Kryscio SJ. Tooth loss, dementia and neuropathology in the Nun Study. J Am Dent Assoc. 2007; 138: $1314-1322$. 
6. Okamoto N, Morikawa M, Okamoto K, Habu N, Iwamoto J, Tomioka K, Saeki K, Yanagi M, Amano N, Kurumatani N. Relationship of tooth loss to mild memory impairment and cognitive impairment: findings from the fujiwara-kyo study. Behavioral and Brain function. 2010; 6: 77 (diunduh September 2014). Tersedia dari http://www.behavioralandbrainfunctions.com

7. Tsutsui K, Kaku M, Motokawa M, Tohma Y, Kawata T, Fujita T, Kohno S, Ohtani J, Tenjoh K, Nakano M, Kamada H, Tanne K. Influences of reduced masticatory sensory input from soft-diet feeding upon spatial memory/learning ability in mice. Biomedical Research. 2007; 28(1): $1-7$.

8. Yamamoto T, Hirayama A, Hosoe N, Furube $M$, Hirano S. Effect of soft-diet feeding on BDNF Expression in Hippocampus of Mice. Bull Tokyo Dent Coll. 2008; 49(4): 185 - 190.

9. Yamamoto T, Hirayama A, Hosoe, N, Masaru F, Hirano S. Soft-diet feeding inhibits adult neurogenesis in Hippokampus of Mice. Bull Tokyo Dent Coll. 2009; 50(3): 117 - 124.

10. Sari KI, Farenia R, Purba A. Effect soft-diet feeding and hard-diet feeding with aerobic voluntary wheel running on hippocampus in Wistar rat. In Redjeki S, Farida R, Fatma D, Tjahajani A, Utami S, Leepel L, editors. Proceeding of Regional Oral Biologi Scientific Meeting; 2014 Oct 30-31; Depok. West Java: Indonesia, 2014: 68-73.

11. Kraemer WJ, Fleck SJ, Deschenes MR. Exercise physiology. For Health, Fitness and Performance. $3^{\text {rd }}$ ed; 2011. 1 - 20.

12. Wilmore $\mathrm{J}$, Knuttgen $\mathrm{H}$. Aerobic exercise and endurance improving fotness for health benefits. The physician and sportsmedicine. 2003; 31(5): 45.
13. Kim JM, Stewart R, Prince M, Kim SW, Yang SJ, Shin IS, Yoon JS. Dental health, nutritional status and recent-onset dementia in a Korean community population. Int J Geriatr Psychiatry. 2007; 22: $850-855$.

14. Yeh Chih-Ko, Katz MS, Saunders MJ. Geriatric dentistry: integral component to geriatric patient care. Taiwan Geriatrcs \& Gerontology. 2008; 3(3): 182 - 192.

15. Sheiham A. Oral health, general health and quality of life. In Bulletin of the World Health Organization. 2005; 83(9): $641-720$.

16. Garcia N, Miley DD. The oral cavity and nutrition. In: Morly JE, Thomas DR. Geriatric Nutrition. CRC Press; 2007. 249 - 265.

17. Thalib B. Analisis hubungan status gigi dengan pola makan dan asupan nutrisi pada manula suku Bugis dan suku Mandar. Dentofasial. 2008; 7(1): 27 - 37. Tersedia dari http:// wwwjdmfs.org.

18. Wangsarahardja K, Dharmawan OV, Kasim $E$. The correlation between oral health status and the quality of life in the elderly. Universa Medicina. 2007; 26(4): 186 - 194.

19. Scherder E, Posthuma W, Bakker T, Vuijk PJ, Lobbezoo F. Fungsional status of masticatory system, execituve function and episodic memory in older persons. Journal of Oral Rehabilitation. 2008; 35: $324-336$.

20. Kubo K, Chen $\mathrm{H}$, Onuzuka M. The relationship between mastication and cognitive. Dalam Senescence and Senescence-Related Disorders. 2013(2) [diunduh 3 Maret 2013]. Tersedia dari Intechopen Reference Online. http:// wwwintechopen.com. 